\title{
MULTILITERACIES AND LANGUAGE IDEOLOGIES IN CONTEMPORARY FANFIC LITERACY PRACTICES
}

\section{MULTILETRAMENTOS E IDEOLOGIAS LINGUIISTICAS EM PRÁTICAS CONTEMPORÂNEAS DE LEITURA E ESCRITA DE FANFICS}

\section{Patrícia de Souza Martins ***}

\begin{abstract}
Using the lens of Street $(1984 ;$ [1995]2014; 2003; 2010; 2012), this article firstly aims at discussing the contemporary literacy practices young readers and writers of fanfics engage in when inserted in the affinity spaces of fan literature. This discussion is based on the concept of ideological literacy proposed by the author and dialogues with the concept of multiliteracies, outlined by the New London Group (CAZDEN; COPE et al, 1996) and expanded by several authors such as Cope; Kalantzis (2000), Gee (2000), Rojo (2012) and Kleiman; Sito (2016), among others. These contemporary literacy practices, understood, therefore, as the social use of language, were studied from an ethnographic perspective (HEATH; STREET, 2008). Data was generated from the field observation on two fanfic self-publishing platforms and from literacy events occurring in rounds of conversation, within the scope of the Junior Scientific Initiation Project. (PICJr-049), promoted by a traditional federal institution of basic education in Rio de Janeiro. The social models of literacy used by participants in literacy events (HEATH, 1982; STREET, 2012) signals that designs are (re)shaped according to the interactional context of these participants. This article also proposes a reflection on the language ideologies underlying the discourse of the students participating in the PICJr-049. This analysis is oriented by Volóchinov's concept of ideology ([1929]2017) and the notion of language ideology, as discussed in the studies by Woolard (1998) and Kroskrity (2004). In the analysis, it was observed that the students reinforce language ideologies anchored in the legitimation of the educated norm of the Portuguese language and in the privilege of literary canons in school literacy practices. Keywords: fanfics; multiliteracies; language ideologies.
\end{abstract}

\section{RESUMO}

Este artigo se propõe, em primeiro lugar, a discutir, a partir das lentes de Street (1984; [1995]2014; 2003; 2010; 2012), as práticas contemporâneas de letramento em que jovens leitores e escritores de fanfics se engajam quando inseridos em espaços de afinidade da literatura de fãs. Essa discussão apoia-se no conceito de letramento ideológico proposto pelo autor e dialoga com a concepção de multiletramentos, delineada pelo Grupo de Nova Londres (CAZDEN; COPE; et al, 1996) e expandida por diversos autores como Cope; Kalantzis (2000), Gee (2000), Rojo (2012) e Kleiman; Sito (2016), dentre outros. Compreendidas, portanto, como o uso social da linguagem, essas práticas contemporâneas

\footnotetext{
* Universidade Federal do Rio de Janeiro (UFRJ), Rio de Janeiro, RJ, Brasil pdsmartins@ufrj.br

** Colégio Pedro II, Rio de Janeiro, RJ, Brasil. pdsmartins@gmail.com.

Orcid: https://orcid.org/0000-0001-7978-7165
} 
de letramento foram estudadas em uma perspectiva etnográfica (HEATH; STREET, 2008). Os dados foram gerados a partir da observação no campo virtual de duas plataformas de auto publicação de fanfics e a partir dos eventos de letramento ocorridos nas rodas de conversa, no âmbito do Programa de Apoio a Projetos de Iniciação Científica Jr. (PICJr-049), promovido por uma instituição federal de educação básica no Rio de Janeiro. Os modelos sociais de letramento a que os participantes recorrem nos eventos de letramento (HEATH, 1982; STREET, 2012) sinalizam que os designs são (re)desenhados de acordo com o contexto interacional desses participantes. Em um segundo momento, se propõe a refletir sobre as ideologias linguísticas presentes nos enunciados dos estudantes participantes do PICJr-049. Essa reflexão é orientada pelo conceito de ideologia concebido por Volóchinov ([1929]2017) e pela noção de ideologia linguística, conforme discutida nos estudos de Woolard (1998) e Kroskrity (2004). Na análise desses enunciados, foram observados posicionamentos que reforçam ideologias ancoradas na legitimação da norma culta da língua portuguesa e no privilégio dos cânones literários nas práticas de letramento escolar.

Palavras-chave: fanfics; multiletramentos; ideologia linguística.

\section{INTRODUCTION}

Fan fiction - abbreviated fanfic or just fic - represents one aspect of fan engagement with a fandom ${ }^{1}$. It is one of the diverse fan-created works which can be broadly defined as "the imaginative interpolations and extrapolations by fans of existing literary world" (HELLEKSON; BUSSE, 2014, p. 6). The authors argue that a variety of texts can be included and excluded in this definition, depending on the specificness one chooses to work with. The study discussed in this article draws on the view of fan fiction as "historically situated in the last forty years, tending to respond to a specific form of media texts, and encompassing a specific amateur infrastructure for its creation, distribution and reception" (HELLEKSON; BUSSE, 2014, p. 7).

Fan fiction started with the zine ${ }^{2}$ culture, having as a basis the TV show Star Trek. Today fan-created narratives are published on digital platforms and depict either characters from literature, movies and Tv series or the imagined life of a leading pop singer or an actor/actress. These digital platforms have changed the way fan fiction is produced, published and read, representing a new space for what can be understood as fan literature, which is, echoing Bakhtin ([1979]2016), a new field of human activity. This article aims, therefore, at discussing contemporary

1. Fandom - fan + (king) dom - is a term used to refer to a fan subculture that emerges around a celebrity, a movie, a Tv show or a movie character, among others. The individuals belonging to a certain fandom share common interests and develop a sense of camaraderie.

2. Zine is short form for fanzine, which is a magazine written by and for fans. 
literacy practices which orient the (inter)actions between fanfic readers and writers on online fanfic self-publishing platforms.

As a teacher of Basic Education, I have always been aware of the impact of media - and, more recently, digital media - on adolescents' learning processes. That is why getting to know some students of mine were using their smartphones to read fan fiction in class immediately caught my attention. My first thought was that I could use a popular story as a reading assignment and, without much reflection, I hastily asked my students for suggestions of titles. To my surprise, I was told stories are not chosen by title, but by several distinct criteria shared by fans who write and read fan fiction on-line. I have then realized the notion of fan fiction as fiction written by fans was not only insufficient to understand the textures of the narratives created and read by fans, but also required a theoretical scrutiny on the subject.

At that point, fan fiction was regarded as a "pedagogical tool" (HELLEKSON; BUSSE, 2014, p. 9) and my problem of study was to understand how (and if) the use of fan fiction in collaborative and intertextual reading/writing assignments could contribute to the learning of English as an additional language. Based on the premise that literacy practices are culturally constructed and that to understand literacy practices, it is necessary, as Barton and Hamilton (2000) assert, to document the ways in which literacy is historically situated, I adopted an ethnographic perspective to literacy research $\left(\mathrm{HEATH}_{i}\right.$ STREET, 2008) to conduct a study with students who were readers and/or writers of fanfics. I submitted a research project to the Junior Scientific Initiation Program of a federal school in Rio de Janeiro, Brazil (where I teach). The project - PICJr-049 - was approved and supervised by the Dean of Graduate Studies, Research, Extension and Culture of this same institution. The research ${ }^{3}$ was carried out from June through November 2017 and four students, ranging 13 to 16 years old, were granted scholarships.

In pursuit of a comprehensive description of the contemporary practices of writing and reading fanfics, data were generated by: (i) registering, with the aid of print screen resource, features and interactions occurring on online platforms for (self)publishing and (ii) recording rounds of conversation carried out within the scope of PICJr-049. The results of this study signaled that the focus of the study should shift from fan fiction as a pedagogical tool to fan fiction as "one element of audience response" (HELLEKSON, BUSSE, 2014, p. 9). According to this model of approaching fan fiction,

3. It is important to note that this research followed ethical procedures. The students had their names replaced by fictional ones and their legal guardians signed the Informed Consent Form provided by the institution. 
media invites complex and diverse audience responses that should not be simplified into a binary division of viewers who incorporate the intended message and ideology and those who choose to subvert it. In its stead, they [Abercrombie; Longhurst, 1998] suggest a model where viewers engage with the programs on multiple levels, negotiating the myriad messages and responding with interpretations and performative responses of their own.

This understanding made me focus on the audience response of a fanfic reader. Therefore, the second phase of the study consisted of my immersing in online fanfic self-publishing platforms in order to generate data from this virtual field of observation. Also, I submitted another project to the Junior Scientific Initiation Program - PICJr-061 - to research on multiliteracy practices young people engage in when reading and/or writing fan literature on platforms which had gone mobile. There were four students involved in the project ${ }^{4}$, ranging 16 to 18 years old, which enabled me to deal with adult narratives. This project was carried out from May through November 2019 and had as the main objective to provide a theorical description of the ideological literacy practices as well as the multiliteracy practices engendered by members of fanfic affinity spaces. An affinity space is understood in this study as

a place (physical, virtual, or a mixture of the two) wherein people interact with each other, often at a distance (that is, not necessarily face-to-face, though face to face interactions can also be involved), primarily through shared practices or a common endeavor (which entails shared practices), and only secondarily through shared culture, gender, ethnicity, or face-toface relationships (GEE, 2004, p. 89).

Considering that the interactional practices in fanfic affinity spaces represent a social use of language in a field where power relations among readers, authors and editorial market have clashed, the analysis of the study presented in this article draws on the ideological model of literacy (STREET, 1984; 2003). To do so, I will focus on the social practices in which contemporary fanfics are embedded, accounting for the cultural diversity and the use of multimodal language in digital environments. For this reason, I will add to this analysis the concept of Multiliteracies (NLG, 2000; COPE; KALANTZIS, 2000; GEE, 2000; KLEIMAN; SITO, 2016 and ROJO, 2012), aligned with the studies of Kress; Rowsell (2019). The authors argue that changes in the contemporary society, such as the crescent dominance of digital screens as "means of (production and) dissemination of meaning-as-texts" and the dominance of the neo-liberal market where an individual is seen as a consumer

4. This research project followed the same ethical procedures of PICJr-049 and the students - or their legal guardians - signed the Informed Consent Form provided by the institution. 
produce different "effects in communication and in, on, and around 'literacy" (KRESS, ROWSELL, 2019, p. 32-33).

Another point of reflection I will bring to this article are the language ideologies underlying the interactional practices in fanfic affinity spaces. The analysis is oriented by Volóchinov's concept of ideology ([1929]2017) and the notion of language ideology, as discussed in the studies by Woolard (1998) and Kroskrity (2004).

For organization purposes, I will design the circumstantiated discussion in two parts. In part one, section 1, I will describe fanfics as ideological literacy practices and as (multi)literacy practices on Spirit Fanfics e Histórias platform. In section 2, and I will discuss the Wattpad platform, highlighting the clash of power relations in fan literature. In part two, section 3, I will analyze the language ideologies that underlie the discourses of the participants of the project PICJr-049.

\section{FANFICS AS IDEOLOGICAL LITERACY PRACTICES}

Approaching fan fiction as "one element of audience response" (HELLEKSON; BUSSE, 2014) - as discussed in the introduction of this article -, requires a theoretical understanding of literacy anchored in the ideological model (STREET, 1984), since writing and reading fanfics imply issues of social use of language, identity construction and clashes in power relations. Unlike the autonomous literacy model - which focuses on neutral and technical-skilled reading and writing - the ideological literacy model considers literacy a social practice and is, therefore, as Street ([1995]2014) points out, concerned with general social institutions - not only schools - through which the process of socialization takes place. It is important to note that the assumption of neutrality that characterizes the autonomous model of literacy is in itself ideological and fallacious, since the very act of assuming anything as neutral and technical is itself an ideological position (STREET, [1995]2014).

Maybin (2000) discusses the conception of the ideological model of literacy by adding Foucault's view of discourse which states that power relations permeate the social body (FOUCAULT,1980). In her studies, Maybin (2000) highlights that the social use of language in local events promotes the insertion of individuals into discursive patterns associated with broader social institutions, which (re)shapes their conceptions of truth, knowledge, power, and subjectivity. In this ideological model of literacy, 
events represent the instantiation of an unstable, contested ideological world within everyday verbal exchange, and these studies analyze some of the complex processes through which individual identity, social relationships and institutional structures are instantiated and negotiated through what people actually say and do with texts. (MAYBIN, 2000, p.206)

A fanfic, as a fan text, is written as an audience response resulting from a clash in power relations when the reader, as a fan, contests some aspects of the source text (any media text considered) or (re)shapes the end or the personality of one of the characters, just to cite some examples. That happens, as Jenkins (2012) suggests, because

\begin{abstract}
fan culture reflects both the audience's fascination with programs and fans' frustration over the refusal/inability of producers to tell the kinds of stories viewers want to see. Fan writing brings the duality of that response into sharp focus: fan writers do not so much reproduce the primary text as they rework and rewrite it, repairing or dismissing unsatisfying aspects, developing interests not sufficiently explored (JENKINS, 2012, p. 162).
\end{abstract}

Engaging with the ideological model of literacy presupposes understanding that "the ways in which people address reading and writing are themselves rooted in conceptions of knowledge, identity, and being "(STREET, 2003, p. 77-78). As far as fan fiction is concerned, not only does the writing of a fanfic represent the instantiation and negotiation of individual identity, social relationships and institutional structures but also how to address the reading of a fanfic represents power negotiation. Fanfic readers frequently comment on aspects of the narrative: they may complain the fanfic writer is not loyal to the fandom they share; they may criticize the lack of coherence of the text; they may suggest plot change or scene insertion, they may praise the quality of the text, among other interventions.

The analysis of the literacy practices inherent in the fanfic affinity spaces is, therefore, based on New Literacy Studies (GEE, [1990]2008) since it is grounded "on the view that reading and writing only make sense when studied in the context of social and cultural practices (and we can add historical, political and economic) of which they are only a part" (GEE, 2000, p. 180). To conduct a micro-analysis of these literacy practices, I have opted to distinguish the local usage from more global uses of language by building on the conception of literacy events (hereinafter, LE) as "occasions when written language is integral to the nature of participants' interactions and their interpretive processes and strategies" (HEATH, 1982, p. 50) and on Street's (1984) conception that uses the term literacy practices (hereinafter, LP) as a way of focusing on the social practices that involve reading and writing. Street elaborates his concept taking into consideration the meaning of events, as postulated by Heath (1982), and the "social models of literacy that participants 
bring to bear upon those events and that give meaning to them" (STREET, 2003, p. 78 ).

Figures 1 and 2 below are excerpts of diverse literacy events which are embedded in social practices that take place in the social and cultural context of the fanfic Conquistando Ucbiba. ${ }^{5}$ The criterion used for the selection of this fanfic was the fact that it was ranked as the most read of the week on the date I did the virtual search, on $07 / 03 / 2018$.

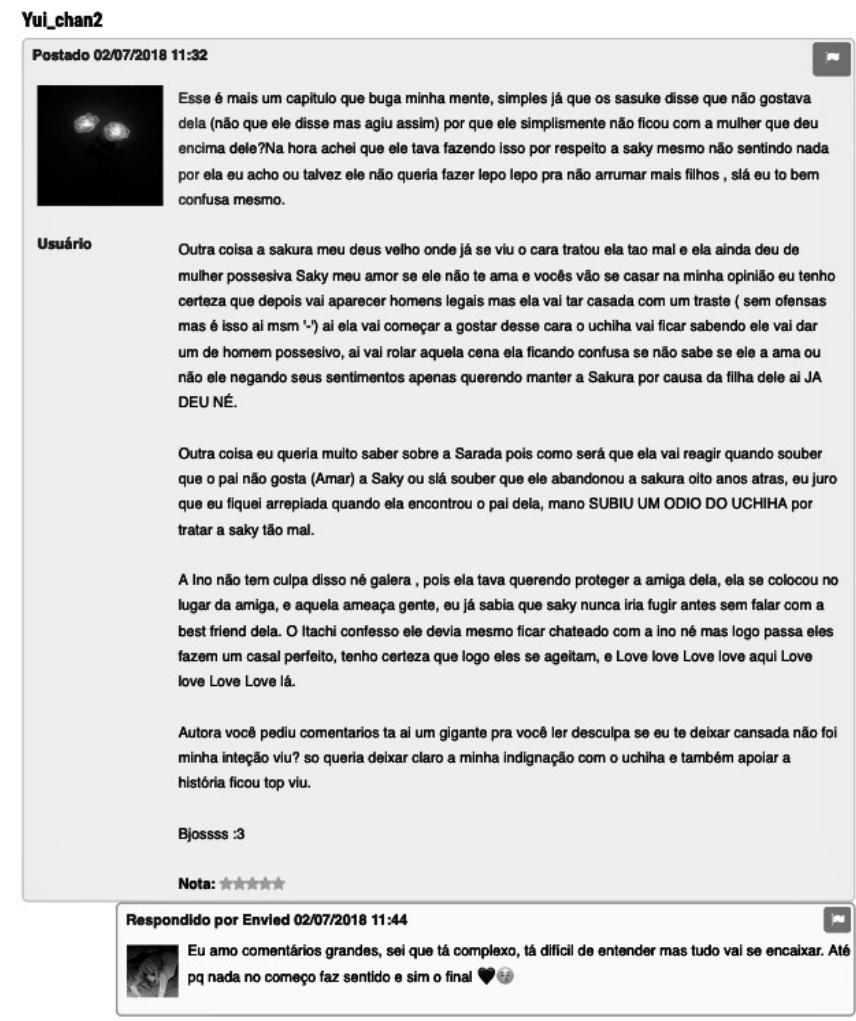

Sra_Chipa

Figure 1. Reader's comment ${ }^{6}$

Available in:https://www.spiritfanfiction.com/historia/conquistando-o-uchiha--sasusaku-13475388/ capitulo8 (Assessed on 07/03/2019)

5. Uchiha is one of the clans in the well-known anime and mangá Naruto.

6. Due to space restriction, a translated version of the LE depicted in Figure 1 can be found in appendix 1 . All translations in this article are of my entire responsibility. 
In Figure 1, Yui_chan2 does not merely evaluate - assigning the five-star rating - and review the chapter of the story. The reader gives her opinion, describes her reactions to her reading of the story, and inquiries about upcoming events. Moreover, in this LE, we can realize that Yui_chan2 mobilizes three interactional contexts. In the first interaction: "Ino is not to blame for that; you know, guys [?]", the reader addresses to the audience who is reading the same story, trying to explain what seems obvious to her. In the second interaction: "Saky, my love, if he doesn't love you and you are getting married [...]", the reader addresses directly to the story character Sakura to advise her not to marry. The reader even apologizes to Sakura: "No offense, but that's it [she refers to the husband-to-be as a despicable person]". In this very same interaction, the reader alternates from opinion and advice by addressing to the character either in the first or third person. In the third interaction: "Author, you asked for comments [...], the reader talks to the story's writer, using the word author as a vocative, to apologize for the long comment: "[...] sorry if I make you tired; I didn't mean it, ok?"

Another important aspect of this LE can be observed when the reader addresses to other readers using as a vocative the Portuguese word "galera" (guys). This word signals familiarity or friendship, so its use not only inserts the reader in the fanfic affinity space, but also enables her to use a rhetorical question to establish a link of affinity with the group by sharing the same opinion. It is also worth pointing that when interacting with the author, Yui_chan2 construes herself as a fan of the story whose long text violates the rule of short comments on social media. Although, as a fan, she can break an internet law to support the story, as a reader, she subjects to the author's authority: she apologizes and explains why she has written a long comment. This negotiation of power relations will be further analyzed in figure 2 which is a print screen of a written text (with its translation on its side).

7. I consider the reader Yui_chan2 identifies with the female gender because Yui Chan is a girl in the anime/mangá universe. 


\begin{abstract}
Notas do Autor
Gente deixa eu explicar uma coisas para vocês que estão bem confusos. Eu estou abordando uma reaproximação de 2 pessoas em uma vida adulta, não posso escrever algo romântico e surreal como a primeira temporada por esses simples motivos: $1^{\circ}$ eles tinham 20 anos na época a cabeça era evoluída porém não tanto como agora. $2^{\circ}$ tem uma criança envolvida.

De certa forma um casamento seria apropriado a criança poderia viver com seus pais tratando seu trauma infantil de nẵo ter um pai por perto.

E por último a relação não vai ser a mesma, os dois estão desgastados com a vida adulta. Sasuke agora é podre de rico, ele tá mimado e com toda certeza consegue ter toda mulher em sua cama, isso sobe para cabeça. E sobre ele tá sendo babaca isso vail dividir opiniões até o fim da fanfic quando tudo se encaixar, como eu disse eu nunca dou um ponto sem explicaçăo, e essa explicação vai chegar. Não quero romantizar mulito um relacionamento adulto porque sabemos que um relacionamento entre pessoas maduram tem suas inúmeras recaídas, não é só conto de fadas. Porém não estou dizendo que não vai existir um romance, vai mas em momentos certos, em ocasiöes certas. Obrigada pela atenção pessoal, desculpa fazer uma explicação grande, espero ter tirado a limpo algumas dúvidas.

Enfim boa leitura

Capítulo 10 - Capítulo IX
\end{abstract}

Figure 2. Author's note

Translation $^{8}$

Guys let me explain a things [sic] to you who are very confused. I am approaching the reunion of 2 people in their adult lives, I cannot write something romantic and surreal like the first season due to these simple reasons: $1^{\text {st }}$ They were 20 years old then [they] were openminded, but not so much as now.

$2^{\text {nd }}$ There is a child involved

Somehow a marriage would be appropriate the child would live with bis/her parents treating his/her child trauma of not baving a father nearby.

Finally the relationship is not going to be the same, both are weary with the adult life. Sasuke now is rotten rich, be is spoiled and surely gets to take every woman to bed, this goes to bis bead. And about bis being an asshole this will split opinions until the end of the fanfic, when everything will fit, as I said I never write anything without an explanation, and this explanation will come. I don't want to romanticize an adult relationship very much because we know a relationship between mature people bave countless relapses, it's not only a fairy tale. But I'm not saying there won't be a romance, it will bet at right moments, in right occasions. Thanks for the attention, folks, sorry for writing such a long explanation, [I] bope I bave clarified some doubts

At last bave a nice reading

\section{Availablein:https://www.spiritfanfiction.com/historia/conquistando-o-uchiha--sasusaku-13475388/ capitulo10 Accessed on 07/03/2018}

The LE depicted in Figure 2 may lead to a hasty analysis due to recurrent author's notes present in print editions of books. However, the meaning making process of this genre needs to consider the context of the social and cultural practices of contemporary fanfics and the resulting new relations between writers and readers.

The first point for reflection is that this note is a response to comments, in which readers have claimed to be confused by the narrative plot -eight chapters were already published. In the first lines of this response: "I cannot write something romantic and surreal like the first season for two reasons $[\ldots]^{\prime \prime}$, the author tries to justify her ${ }^{9}$ choices by arguing that the story could not have been narrated

8. In this translation, I have opted to keep the author's style, punctuation and language structure.

9. I consider the author Envied identifies with the female gender because she thanks her reader with "obrigada", which linguistically positions the individual as a female as far as the Portuguese language is concerned. 
otherwise. Besides containing justifications for the readers' complaints, this author's note hybridizes another genre: a prologue, in which the author warns that the character's behavior will keep controversial "until the end of the fanfic, when everything will fit". The author also goes on justifying herself and anticipating that "this explanation will come". As for the dissatisfaction of the readers, the author does not seem willing to review and change the plot line of the character, which characterizes her writing style as of an author of printed books who cannot alter the narrative once it is finished and already published.

Secondly, this interaction reconfigures the relationship between the author Envied and her readers. In the fragments: "Guys let me explain a things [sic] to you who are very confused" and "(...) I hope I have clarified some doubts", prototypical classroom practices are flagged in Envied's lexical choices. Envied discursively construes herself as a teacher who has the knowledge and seizes this power by holding relevant information to the understanding of the story. This is ratified in her answer (figure 1), when she admits she knows the plot line is complex and difficult to understand, but yet, she refuses to negotiate meaning: she only tries to calm down her readers reaffirming that everything will make sense in the end.

The analysis of figures 1 and 2 focused on the social practices authors and readers engage when interacting in the affinity spaces of fanfics. To study the social use of multisemiotic language in a pluricultural context featured by the online platforms for publishing fanfics, I will rely on the concept of Multiliteracies to be discussed in the next section.

\subsection{Multiliteracy practices on online fanfic self-publishing platforms}

I will start the discussion in this section by presenting in Table 1 an excerpt of a round of conversation within the scope of PICJr-049. This sheds light on the cultural repertoire of young people whose social practices have been strongly influenced by pop culture and mediated by digital devices and social media.

Table 1. Choosing a fanfic to read ${ }^{10}$

Luna: Tags WITHOUT SPOILER. Because I don't like it with Spoiler.

Nilo: From Naruto. There are tags of Naruto, Sasuke, SasuNaru, NaruSasu... Ana Lua: I search the ship before to see if it's right.

Luna: I select a lot of filter. Because in the site I use to read, you select the status you want $t_{i}$ and there are filters for you to filter and you tag what you want. [...]

10. Excerpt translated into English by me. 
Source: Round of conversation within the scope of PICJr-049 (10/18/2017)

When talking about how they choose a fanfic to read, Luna, Nilo and Ana Lua use the terms: (i)ship, a short form for relationship, which is often used to refer to the readers' desire to support a romantic relationship between a fictional character or a real person, mainly a singer or an actor/actress; (ii)tag, which identifies the subject of the fanfic by describing, categorizing or labeling it; (iii)status, which indicates whether the story is complete or still in the process of chapter publishing and (iv) filter, which is a search engine readers use to select stories according to keywords provided. This illustrates a few aspects of computer-mediated communication which, as Luke (2000) had already pointed out,

are producing radically different - blended, merged, and reshaped - social practices and conceptions of community, subjectivity, time, space, textuality, and communication from those formulated in traditional print-based models. These changes and differences point to the need to consider an expanded definition of literacy to take account of multiple forms of textual, graphic, and symbolic languages, as well as the culturally diverse virtual communities of the global mediascape (LUKE, 2000, p.75).

This need for an expanded definition of literacy that incorporates the plurality that comes from the major changes caused by new media, especially digital media, is shared by Gee (2000) when the author states that his study seeks

to place language, literacy, and learning in the broad context of these new alignments, alignments from which new 'kinds of people' are emerging. These issues are, as well, the backdrop against which the Multiliteracies Project has been carrying out its discussions and from which it is making its proposals (Gee, 2000, p. 43).

The project Gee (2000) refers to was an initiative of a group of researchers who met in 1994 to discuss the new contours of the concept of literacy in a rapidly changing context. This group, known as the New London Group (NLG), brought together scholars from a variety of linguistic and educational backgrounds - Cazden, Cope, Fairclough, Gee, Kalantzis, Kress, Allan Luke, Carmem Luke, Michaels, Nakata and Lo Bianco - and decided that the results of their discussions could be "encapsulated" (COPE; KALANTZIS, 2000, p. 5) in the word "Multiliteracies" because

it describes two important arguments we might have with the emerging cultural, institutional, and global order. The first argument engages with the multiplicity of communications channels and media; the second with the increasing salience of cultural and linguistic diversity (COPE; KALANTZIS, 2000, p. 5). 
In this discussion, it is important to highlight that the prefix multi- may lead to conceptual misunderstandings of the notion of multiliteracies presented by the NLG. Street (2012) warns that the use of concepts such as multiple literacies can lead to a pedagogical approach as a metaphor for competence. The author points out that when developing a multiliteracy approach, it is important to

to avoid the determinism of the channel or of the technology, in which the visual literacy in itself is considered to have certain effects that may differ from computer literacy. Thus, the focus would be on the mode, on the visual, and on the computer, and not on the social practices in which computers, visual media, and other types of channels concretely receive meaning. I would like to argue that it is the social practices that attribute meanings and lead to effects rather than the channel in itself (STREET, 2012, p. 74).

Thus, the concept of multiliteracies, as discussed above, is the foundation of this second moment of an ethnographic description of the diverse literacy practices young people engage in on online fanfic publishing platforms. The affinity spaces of fanfics bring together not only diverse cultural exchange practices enabled by the globalization process and the digitally connected society but also incorporate multimodal practices that intersect written texts, animations, icons, boxes (for emails, comments, messages), shapes, videos, sounds, photos, graphics, among others.

Having young teens writing and reading stories about K-pop ${ }^{11}$ idols in which the written narrative is intertwined with remixed images, songs and videos is only one of the many examples of multiliteracies practices. This supports Rojo's (2017) understanding that the growing need to use multimodal language "means that the reading and writing capabilities of letter or print literacies are no longer sufficient for contemporary life" ${ }^{12}$ Figure 3 illustrates these two dimensions: (i) plural semiotic systems and modes of communication and (ii) linguistic and cultural diversity.

11. K-pop is the abbreviation of Korean pop used to refer to a genre of popular music originated in South Korea. The K-pop culture has been spread worldwide and is very popular among young girls for combining in one band multiple boys who feature a choreographed dance and switch their positions while singing

12. Original text: [...] quer dizer que as capacidades de leitura e escrita dos letramentos da letra ou do impresso não são mais suficientes para a vida contemporânea. 


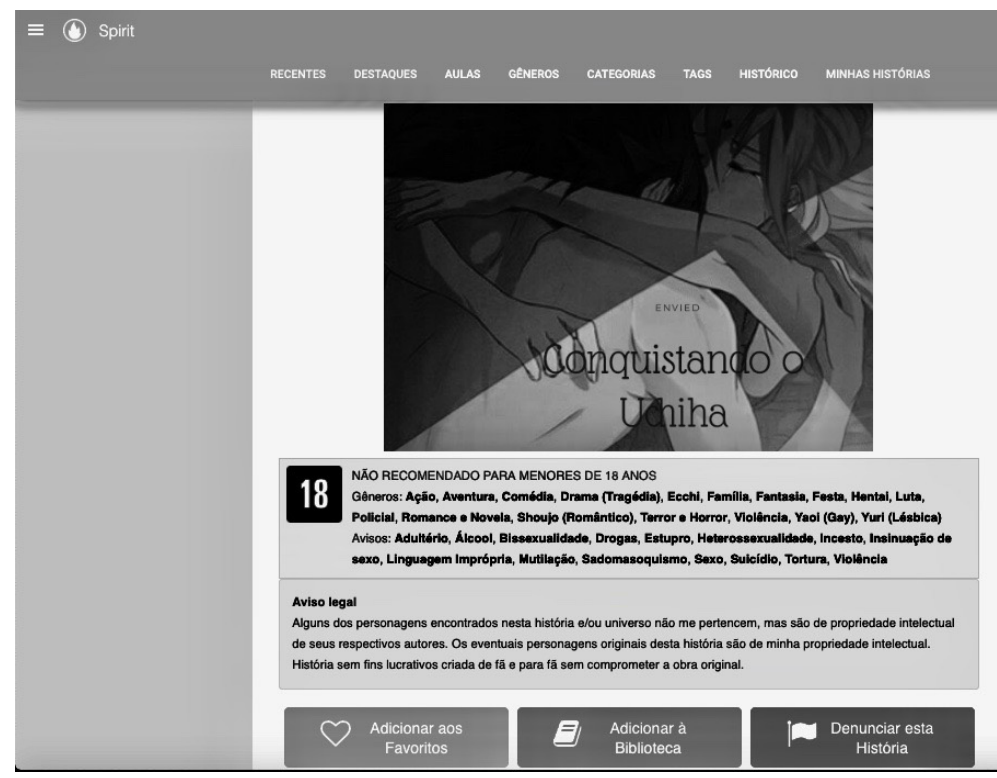

Figure 3. Presentation of Conquistando o Uchiha

Available in: https://www.spiritfanfiction.com/historia/conquistando-o-uchiha--sasusaku-13475388 (Assessed on 07/03/2019)

Firstly, it is important to note that Conquistando o Ucbiba is hosted on the $<$ www.spiritfanfiction.com $>$ website, featuring, therefore, different production, distribution and consumption practices if compared to the fanfics published in fanzines. ${ }^{13}$ Secondly, the possibility to use multimedia, linking tools and social media resources reshapes the multimodality of printed fanfics. In figure 3 , besides the verbal text and the drawing image, there are three icons inserted in different colored boxes, representing specific practices of the social networks that have been imported from popular social media platforms. The heart icon, placed in an orange box in the original text, indicates that the story can be added to a favorite list; the book icon, placed in a blue box in the original text, indicates that the story can be saved to be read offline; and the flag icon, placed in a red box in the original text, appears as a reference to the verb "flag" in English. As one of the meanings of this verb is to mark or identify with or as if with a flag, the flag indicates that the reader can denounce any improper condition of the publication by clicking on this icon.

Figure 3 also presents an excerpt of the Japanese mangá culture. The drawing image depicts a couple sketched with the typical manga striking features. Also,

13. A magazine written by and for fans. 
the main character of the story - Uchira - belongs to an important clan in the Naruto universe. The couple is kissing, and the position of their bodies together with the 18-year-classification sign on he left, suggest they are engaged in a sexual intercourse.

Another cultural practice observed in figure 3 is the use of FanArt. In Fandom affinity spaces, fans who are amateur artists or like to experiment with digital arts produce their own work based on a well-known character, on a movie item or even on a work that was created by fans of a fanfic, for example. Although the fanfic author's name Envied is written on the drawing image, the authorship of the FanArt is not explicit, since it lacks a signature or an explanatory note. Copyright laws are still a sensitive discussion matter as far as FanArt and fanfics are concerned.

The FanArt selected by Envied to appear in her fanfic represents the Fancover of her story. Fancovers for fanfics are believed to be an important element in fanfic writing, since they play a similar role as printed book covers do. Fancovers may be replaced as long as the writer is posting the chapters of the story and, in some platforms, they enable more multimodal options such as songs and videos and the possibility of a Fancover for each chapter.

FanArt can be understood as a remix or mashup culture. Rojo (2012) uses the electronic music remixes and mashups - digital combination of two or more songs to produce a totally new musical piece - as a metaphor for individuals participating in mixed and hybrid cultures. Thus, young people immersed in fanfic and FanArt practices not only develop their own aesthetic criteria, but they also master a series of multiliteracies.

The new (re)arrangements or (re)assemblies fanfics and FanArt provide are configured as an active and dynamic process defined by the NLG $(1996$, p. 74) as re-design. In the light of the multiliteracies concept, a re-design is the produced result that becomes a new design. In a continuous movement, the design becomes a new resource available for new meaning makings. Over two decades later, this semiotic process of shaping meanings, transforming and recontextualizing designs available remains a potent conceptual apparatus to understand the contemporary aesthetic criteria of fanfic and FanArt practices embedded in a remix or mashup culture.

An important point to highlight is that these contemporary multiliteracy practices can transform power relations, create new cultural products, generate new or hybridize discursive genres, build new knowledge, construct new identities, and, especially, provide a new conception of "ethics that is no longer based on ownership (copyrights, income which fade away in the free web browsing) but on the dialogue 
(signed, quoted) between new interpretants (remixers, mashupers)"14 (ROJO, 2012 , p. 18). In the next section, I will briefly discuss new power distribution in fanfic practices.

\section{POWER RELATIONS IN FAN LITERATURE}

In affinity spaces such as platforms for the self-publishing of fanfics, individuals do not need to be related to each other personally to participate in a collectivity. These individuals only need to share a common goal, interest, or fandom. In these spaces, the conventional relations between authors and readers are destabilized, since what bonds them together is the affinity towards a famous actor/actress, singer or movie character. One reason for this destabilization lies in the fact that the fanfic main character(s) is/are already known and cherished by readers who, as fans, feel they can confront the author if s/he is not coherent to the original character(s)', actress/actor(s)' or singer(s)' profile. Another reason for such a conflict has to do with the fact that the author of a fanfic knows s/he has a predisposed audience to read her/his story. This is not for the plot itself, but because the character(s) chosen to star the narrative already has/have a legion of fans and the plot, therefore, is likely to respond to these fans' fantasies about their idols.

It's worth noting that fans - writers and readers - assemble in fanfic affinity spaces due to their desire to fictionalize not only existing fictions but also the real life of a pop icon. Therefore, to proceed the discussion about authorship and self-publication of fanfics, I will consider the fanfic multiliteracies practices as fan literature, grounding my assumption on the human need to fictionalize the world (CÂNDIDO, 2002). The author understands that

[...] either orally or visually; in short and elementary forms, or in complex extended forms, the need for fiction manifests itself in every moment; in fact, no one can spend a day without consuming it, even in the form of a lottery guess, daydream, ideal construction or anecdote. And this justifies the interest in the function of these forms of systematizing fantasy, of which literature is one of the richest modalities (CANDIDO, 2002, p. 83) ${ }^{15}$

14. Original text: "Uma nova ética que já não se baseia tanto na propriedade (de direitos do autor, de rendimentos que se dissolvem na navegação livre da web), mas no diálogo (chancelado, citado) entre novos interpretantes (os remixers, mashupers)".

15. Original text: [...] por via oral ou visual; sob formas curtas e elementares, ou sob complexas formas extensas, a necessidade de ficção se manifesta a cada instante; aliás, ninguém pode passar um dia sem consumi-la, ainda que sob a forma de palpite na loteria, devaneio, construção ideal ou anedota. E assim se justifica o interesse pela função dessas formas de sistematizar a fantasia, de que a literatura é uma das modalidades mais ricas (CÂNDIDO, 2002, p. 83). 
Lajolo (2018), reflecting on the historical and social changes that have occurred over the past three decades, revisits her work in search for answers, albeit tentative, to the complex question: What is literature? The author emphasizes that in a multi-cultural and hypermediatic world, literature also takes on multiple faces. That said, although not always in harmony, canonical literature and esoteric novels, self-help books, haiku poems, comic books, cordel leaflets, and fanfiction go hand in hand.

As far as fan literature is concerned, it is necessary to point out that my focus in this study is not theoretical questions concerning the canon and its implications in the literary studies. My objective here is to contrast the writing, publishing and reading practices occurring in contemporary platforms such as Spirits Fanfics e Histórias and Wattpad to the ones occurring in the printed book market.

In the field of fan literature, some practices can be compared to those ones which are characteristic of the best seller literature, such as a closer contact between authors and readers through social media. However, the fact that the fan literature involves neither professional nor commercial practices, distribution of power emerges as the most striking difference.

First, fanfic authors do not need an editor to approve their texts and they do not need a publishing house to publish and market their fanfics. Fanfics selfpublishing platforms are free: a quick registration grants access to their editing and publishing features. In addition, the most recent platforms have been designed with popular social media tools and have been optimized for mobile devices, adding to fanfics this ubiquitous quality.

Secondly, these social media resources not only enable readers to approach authors directly, but also create contemporary conditions of re-design. The genre comment can refer to a whole chapter, in the same composition style of Facebook, or be related to specific passages highlighted by the readers, as can be seen in e-readers. Thus, this genre hybridizes with the readers' opinion or readers' letter/email who still circulate in magazines or newspapers. Moreover, in certain fanfics, the genre comment may be re-designed as well, seeing that their authors can interact with the readers as if they were using a typical messaging app. Again, power relations are shaken, because authors can have their writing style, or the character creation questioned in a synchronous interaction.

Another peculiar feature of fan literature concerns the tools view, follow and favorite. Following the logic of the consumer market, which operates with best-seller lists, the number of views represents how many times a certain fanfic was accessed. However, these views cannot be compared to purchases because the same reader may access a fanfic how many times s/he wishes. The closest action that can be 
compared to buying a book is following of a fanfic, though it is a resource used for a reader to keep track of new chapters posted by the authors. Neither the view not the follow tool works as an indicator that a fanfic is worth reading. In fanfic affinity spaces, the relevance measure is favoritation, the action of evaluating positively a story by clicking on the heart icon accompanying every fanfic published (see fig. 3). As it is the reader who decides if and when a fanfic should be favorited, authors tend to ask readers to fave their stories so that they can attract more readers and be ranked in top positions. Favoriting a fanfic replaces marketing strategies and changes the logic of a quantitative to a qualitative list as an indicator of a good story.

Throughout the discussion conducted in this section I can assume that the consumer-driven neoliberal economic relations, the dominance of image as a means for meaning making and the advances in digital technology which have allowed complex social practices to be engendered at the touch of a screen have produced evident social changes. These changes have, as Kress; Rowsell (2019, p. 33) argue, "its effects, differently, in communication and in, on, and around 'literacy" [emphasis added by the authors].

The effects of the neoliberal economic relations in, on and around multiliteracies practices will be further discussed by examining three excerpts of the most used platform for fanfic publishing. Figure 4 introduces Wattpad; figure 5 gives a brief description of how Wattpad works; and figure 6 presents some of the Wattpad partners, which are well-known companies, such as Sony Pictures Television, Hulu streaming Tv, SYFY Tv channel, Macmillan Publishers and Penguin Random House.

\section{Hi, we're Wattpad.}
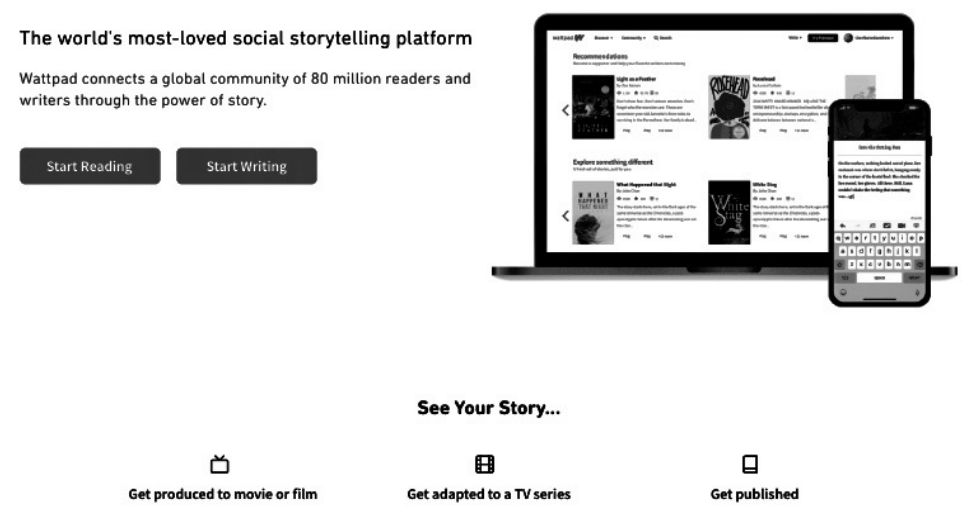

Figure 4. Wattpad_Hi, we're Wattpad

Available in: https://www.wattpad.com (Assessed on 10/06/2019) 


\section{How Wattpad Works}

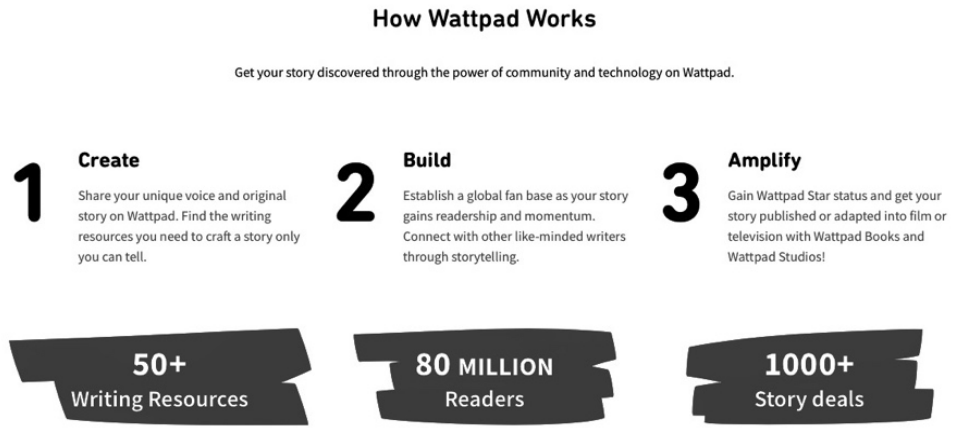

Figure 5. How Wattpad works

Available in: https://www.wattpad.com (Assessed on 10/06/2019)

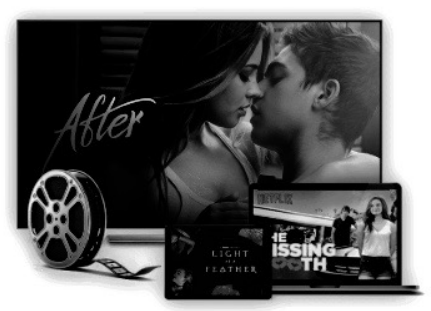

wattpad studios $\mathrm{C}$

Your original story could be the next big hit

Wattpad Studios discovers untapped, unsigned, and

talented writers on Wattpad and connects them to

global multi-media entertainment companies.

Wattpad Studios works with partners such as:

\section{hulu Erenty}

wattpad books

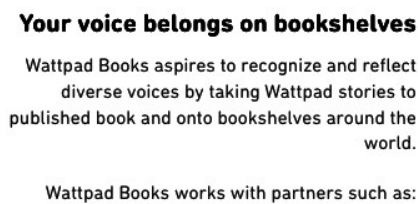

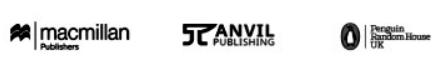

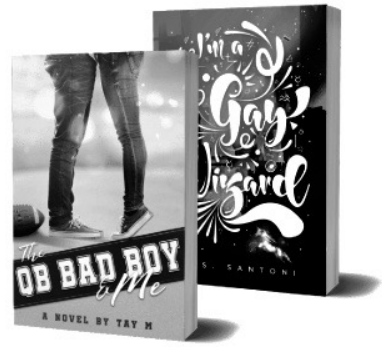

Figure 6. Wattpad partners

Available in: https://www.wattpad.com (Assessed on 10/06/2019)

Figures 4, 5 and 6 depict how Wattpad resignifies non-commercial and non-professional fanfic self-publishing platforms in a fierce struggle to control a market niche constituted by talented writers whose networks belong to a global community of 80 million readers. These readers are viewed by the neoliberal 
market as potential consumers. In figure 4, we can observe that Wattpad introduces the platform by (i) replacing the word fanfic with the word storytelling; (ii) visually informing the platform is optimized for mobile devices; and (iii) explicitly seducing writers to move beyond their affinity spaces and see their stories get produced to movie, adapted to TV or published as a book. To encourage the insertion of fanfic authors into the entertainment industry, Wattpad (figure 5) offers professional aid: they (i) provide the writers with writing technological resources which enhances the multimodal possibilities in the meaning making process; (ii) transfer to the authors the responsibility of stablishing their fan base; and (iii) challenge the authors to gain Wattpad Star status as a condition to have their stories published with Wattpad Books or adapted with Wattpad Studios.

In figure 6 we can observe that the pressure of the neoliberal market puts on talented writers to convince them to connect to global entertainment companies or publishing houses. These changes are likely to affect not only the way the story is narrated - it can become less informal and familiar -but may also impact the genres imbricated in fanfic affinity spaces, since the author's comments may be used more as a marketing strategy than an Author's Note, for example. Also, this probable scenario may cause conflicts with the authors' readers if they understand the story does not match the fanfic aesthetic criteria and/or betrays their shared knowledge about a cherished book/film, character or pop icon.

In this section I have argued that the neoliberal market has realized that the fan literature represents a profitable niche and, therefore, companies like Wattpad has taken over social practices restricted to affinity spaces. This socio-economical change has already clashed with the fanfic multiliteracies practices since hugely viewed fanfics like Fifty Shades ${ }^{16}$, based on the Twilight novel, and After, based on the leading singer of the boyband One Direction ${ }^{17}$ were adapted to books and to movie screenplay. For copyright reasons, the authors of Fifty Shades and After had to rewrite some passages and change the names of the fanfic characters. This was met with immediate backlash by their fans who interpreted this as treason both to the story and to the readers.

These two briefly explained examples above circumstantiate Bloome; Kalman; Seymour (2019)'s understanding of language as social. The authors "take up literacy as social and power relations; how the use of written language is implicated in the ongoing struggle over political, economic, and social hierarchies

16. Originally published on https://www.fanfiction.net/book/Fifty-Shades-Trilogy/ (Accessed on 10/06/2019)

17. Originally published on https://www.wattpad.com/story/5095707-after (Accessed on 10/06/2019) 
(BLOOME; KALMAN; SEYMOUR, 2019, p. 17). Not only literacy (learning how to read and write), but the new literacies studies and multiliteracies advocate the social use of language. Consequently, as the society changes, other changes in the multiliteracies practices are about to happen. Wattpad, for instance, is now displaying ads on the free platform. For those users who do not want to see these ads, the company has just launched a paid pro version. Thus, studying the social and power struggling relations in fanfic multiliteracies casts light on the language ideologies imbedded in these contemporary practices. In the next section I will bring this topic to reflection.

\section{LANGUAGE IDEOLOGIES ENTEXTUALIZED IN FANFIC MULTILITERACIES PRACTICES}

In this section, I selected two excerpts of a round of conversation within the scope of the PICJr-049 project during which ideological constructs on language emerged. Based on the premise that every utterance is ideological, since "where there is a sign there is also ideology" (VOLÓSHINOV ([1929]2017,p. 93) ${ }^{18}$, fanfics multiliteracies practices are conceived as being permeated by "historically crystallized ideologies" and "everyday ideologies" (VOLÓCHINOV, [1929]2017).

Daily ideologies "are featured in a non-systematized way and are expressed more fluidly in the dialogues we engage with others in everyday life, in less formal situations" (SZUNDY, 2017, p. 82).$^{19}$ Although they cannot be attributed to an ideological sphere - scientific, aesthetic, moral, religious, among others - these everyday ideologies are dialectically related to institutionalized ideological spheres. It is because "when materialized in the process of social communication, all ideological sign, including the verbal sign, is determined by the social horizon [emphasis added by the author] of a time and of a social group"(VOLÓCHINOV [[1929], 2017 p. 110). ${ }^{20}$ Thus, these two fields should not be studied in isolation, for our "(inter)actions in the social world always occur in the dialectical interplay

18. Original text: [...] onde há signo, há também ideologia.

19. Original text: [...] se apresentam de forma não sistematizada e são expressas de maneira mais fluida nos diálogos que travamos com outrem no cotidiano em situações menos formais.

20. Original text: [...] ao realizar-se no processo de comunicação social, todo signo ideológico, inclusive o verbal, é determinado pelo borizonte social [grifo do autor] de uma época e de um grupo social. 
between the everyday ideologies and the historically crystallized ideologies" (SZUNDY, 2017, p. 82). ${ }^{21}$

According to Volóchinov ([1929]), 2017) it is in the materiality of the word that the ideological forms of the sign communication can be observed and explained; therefore, language ideologies can be understood as "representations, whether explicit or implicit, that construe the intersection of language and human beings in a social world are what we mean by "language ideology" (WOOLARD, 1998, p. 3).

Woolard (1998) discusses concepts of ideology in order to contextualize some approaches to the studies of language ideology among which I highlight two. The first approach I call upon is "overt intervention: politics, purism and standardization" (WOOLARD, 1998, p. 20), through which ideological analysis addresses questions about how the rules of linguistic correctness and incorrectness are rationalized and how these rules relate to legitimate and valued standards in the spheres of power. The second approach I call upon is "literacy and orthography" (WOOLARD, 1998, p.22), which studies speech, or its written representation, with focus on the orthographic alphabet. It is worth noting that "orthographic systems cannot be conceptualized as simply reducing speech to writing but rather are symbols that themselves carry historical, cultural, and political meanings" (WOOLARD, 1998, p. 23). In this approach, the analysis should focus on the ideology of the value of letter, which assumes that speaking and writing according to a certain standard language, using forms legitimized and valued by dominant groups, inscribe an individual in prestigious social groups. This ideology foregrounds social inequalities and promotes prejudice and discrimination for characterizing as socially and culturally superior, and even more intelligent, individuals who use the standard language in their written and oral texts.

Kroskrity (2004) expands the analytical possibilities to this study by understanding language ideologies as a plural concept used to

circumscribe a body of research which simultaneously problematizes speakers' consciousness of their language and discourse as well as their positionality (in political economic systems) in shaping beliefs, proclamations, and evaluations of linguistic forms and discursive practices (KROSKRITY, 2004, p. 498).

By adding the notion of feelings - in the sense of an automatic aesthetic response - to the notion of beliefs about languages - in the sense of local

21. Original text: [...] (inter)ações no mundo social ocorrem sempre no interjogo dialético entre ideologias do cotidiano e ideologias historicamente cristalizadas. 
understandings, Kroskrity (2004) elaborates a cluster concept of language ideologies, consisting of several converging dimensions. The author, thus, proposes five levels of organization to identify and exemplify language ideologies, both as beliefs about language and as a concept designed to assist in the study of these beliefs. For purposes of analysis, I will focus on group or individual interests. At this layer of significance, "language ideologies represent the perception of language and discourse that is constructed in the interest of a specific social or cultural group" (KROSKRITY, 2004, p. 501).

The theoretical-analytical tool I will invoke to describe the language ideologies imbedded in fanfic social practices and objectified in textual fragments is the concept of entextualization, as proposed by Silverstein; Urban (1996) and Bauman; Briggs (1990). Bloomaert (2005), building on the studies of these authors, defines entextualization as

the process by means of which discourses are successively or simultaneously decontextualised and metadiscursively recontextualised, so that they become a new discourse associated to a new context and accompanied by a particular metadiscourse which provides a sort of 'preferred reading' for the discourse. This new discourse has become a 'text': discourse lifted out of its interactional setting and transmitted together with a new context (BLOOMAERT, 2005, p. 47).

Fabrício (2015) broadens the understanding of this pragmatic concept in linguistic anthropology when she asserts that entextualization is a concept that captures the decontextualizable susceptibility of texts. Texts possess a discursive feature that enables them to travel across contexts. Once texts are produced in one specific context, they become available to be detached from their original communication environment and be relocated in another one. As texts are recontextualized, they integrate the new discourse they are now part of and they become available again to be decontextualized.

Building on the discussion above, I will analyze language ideologies entextualized in fanfic multiliteracies practices reified in "text fragments" (GUIMARÃES; MOITA LOPES, 2017, p.13) generated from the round of conversation, held on 10/18/2017, within the scope of PICJr049. I will begin the discussion by problematizing the issue of prejudice in relation to fanfic reading practices. In Table 2 below, we can observe Mia reporting that her friend Ana had argued that fanfics should not be used as reading material at school, because this is an institution that should privilege the canon, such as Machado de Assis. 
Table 2. We have to read Machado de Assis. ${ }^{22}$

Nilo: I think the prejudice is not necessarily against reading fanfic. It is against what we READ in fanfics. I think that's it.

Luna: I think there is to fanfic...not like that...

Luna: I think that when we mention fanfic, people associate it with a childish thing, or kind of bad writing or bad type, in general.

Luna: Totally amateur.

Luna: It is (...) as if it is not worth much, but there are a lot of fanfics that are very good; better than some books.

Mia: And one of the (inaudible) sheet of paper. There was a friend of mine who said she doesn't think fanfic should be.... Ana.

Luna: What Ana?

Mia: Ana (with a high pitch intonation). She said fanfic should not be used in school, because she thinks that more classic books like Machado de Assis should be used.

Ana Lua: Dom Casmurro!

Mia: Yeah, that's right. She is a person who has a certain prejudice with a fanfic, just because she thinks

Mia: You know.. She thinks the way it is written is not appropriate

Luna: I don't know, because literature is kind of school subject, so we kind of have to read Machado de Assis.

Mia: Yes

Source: Round of conversation within the scope of PICJr-049 (10/18/2017)

Although we cannot infer whether or not Ana has a genuine interest in literature, it can be observed in her discourse that she entextualizes beliefs and values that ratify the canon as a criterion for selecting curricular readings. Her mentioning classic books and Machado de Assis represents the process of decentering these text fragments from the communication environment of school as an institution, such as the literature syllabus in High School, and relocating these fragments in a conversation about fanfics. Ana recontextualizes Machado de Assis and classics books, which originally belong to the discourse of belles lettres and high culture, as a compulsory reading in the literature curriculum. Even hearing from Ana indirectly, it is also possible to assume that her entextualization articulates with the institutional ideological sphere, thus materializing the dialectical play between her everyday ideologies and those historically crystallized by school literature curriculum.

22. Excerpt translated into English by me. 
In addition to that, Ana's discourse is inscribed at the layer of meaning of group interests, as her beliefs and values represent the perception of a language that serves the hegemonic interests of a dominant social or cultural group that, by exercising a privileged position, dictates what is standard, canonical and aesthetically beautiful. Another ideological construct that Ana has entextualized is the notion of a language standardization. The language used by Machado de Assis incorporates what is right, what is beautiful, what has value; therefore, reading his books not only puts an individual in touch with the classical, the erudite, the vernacular, as constitutive of high culture, but also provides him/her with the conditions to acquire the standard language legitimized by the elites. Also, in affirming that fanfics should not be used in the school environment, Ana's discourse reflects and refracts a sense of purism. She makes use of language modality - should and should not - to implicitly express her opinion that fanfics are considered impure genres (CANCLINI, 2011) and should, therefore, be discarded or ignored.

An important point for reflection is that Ana's personal opinion ratifies a still recurrent language ideology that regards purism and standardization as the correct and valued language because they are representative of the prestigious and dominant social classes. Following the analysis of the language ideologies that students entextualize in their discourses, in table 3, I will focus my discussion on the question of misspellings.

Table 3. That fanfic full of misspellings

Pam: Yeah, that fanfic full of misspellings.

Ana Lua: I used to write fanfic that

Ana Lua: My chapters were all messy because I didn't know how to use the platforms' resources.

Pam: Today they are cute, okay, guys.

Ana Lua: Then I organized it right, man... I said: I have OCD [ObsessiveCompulsive Disorder]... I couldn't read fanfic with that stuff anymore... So, I arranged it perfectly.

Ana Lua: I noticed that the number of searches for my fanfic increased a lot, because you know...it was disorganized. And the first chapter (incomprehensible) ... The first impression you have ... if it is full of mistakes... if there is no spacing, no paragraph... everything is together... It [makes people] tired.

[...]

Nilo: I want to pause...very quickly. That... what she said about the misspelling... It's true that in these bad fanfics we classified it.

Nilo: Because there was a time when I was reading a fanfic ... I kept reading the 
story after that mistake because it was a good story... but it was written dry with "i"23 (laughs)

Nilo: I cried reading

Pam: What is it?

Luna: Dry with "i" (laughs)

Pam: I already found hesitate with " $z$ ", I already found hamburger without " $h$ ". I already found

Luna: Toll.

Nilo:- It's tall

Pam: Tall with U, for example.

Nilo: Once I was reading a fanfic there and it didn't make any sense, but the story was good, and I kept reading.

Pam: Yeah, because the idea is good .. but . I can't (murmuring)

Luna: I cannot do that.

Pam: I can't!

Mia: Me neither.

Ana Lua: If I'm reading the third chapter and I can no longer understand there...

Luna: I think that's why I don't read so much fanfic (murmuring)

Pam: I already happened to approach the person and say, "Hey, do you want some help to correct your mistakes?" And the person accepted it.

Nilo: There was a time when I commented like this... Look, I can't understand anything, but I think it's very good.

Luna: (...) like that meme. Look, I thought it was very conceptual, but I didn't understand anything.

Source: Round of conversation within the scope of PICJr-049 (10/18/2017)

When Pam mentions "that fanfic full of spelling mistakes," she brings into the ideological arena the crystallized notion that spelling mistakes disqualify and delegitimate any textual production, even if produced in a coherent, cohesive, and creative way. In the interaction depicted in table 3, participants make a value judgment of fanfic writing determined by the ideological constructions of literacy and orthography.

The discussion on spelling mistakes is interrupted by Ana Lua for she has immediately connected misspelling, a proofreading practice, to criteria of organization, composition and style, an editing practice. She goes on accounting

23. Excerpt translated into English by me. It is important to register that in the examples illustrating misspellings, I changed a letter or a whole word so that the linguistic problem depicted in Portuguese remains the same in English. In some cases, changing a letter does not change the phoneme. 
for improvements she had made in her fanfic. A few moments later, Nilo decides to pause Ana Lua to go back to the orthography topic to problematize that misspelling mistakes should not be a criterion to evaluate a fanfic as a bad one. However, a possible debate does not happen.

These participants go on picking and commenting examples of misspelling and then Nilo once again, underlines a conceptual question: it is not an impeccable orthography that makes a good fanfic. He seems to be referring to coherence when he comments that the fanfic he once read "didn't make any sense". However, he himself demonstrates incoherence in saying "the story was good". In Nilo discourse, the layer of significance literacy and orthography is ideological blurred, since he can't even conceptualize what an error is. Later, in this same literacy event, Nilo takes the blame and admits that he cannot understand the bad fanfic.

After this second interruption of Nilo the other participants continue the debate whether or not they should keep reading a fanfic with orthographic problems. At this moment, it is not clear whether they are referring to misspelling or general mistakes; however, ideologically, standardization is a unanimous criterion for the group to consider a fanfic good. All participants, except Nilo declare they have already abandoned or would not even give a chance to a fanfic containing mistakes. It is worth noting, thus, that these participants have managed to collectively elaborate and operate criteria for fanfic evaluation which are, though, based on the ideology of the value of letter. For them, fanfics, even circulating in a very informal communication environment, must be written in the white, urban and prestige language.

Another language ideology present in this LE has to do with the power exercised by certain groups to dictate what is right or wrong in language matters, thereby manipulating social control mechanisms. As Pam masters the spelling rules, she offers to help a fanfic writer. However, when Pam asks "Hey, do you want some help to correct your mistakes?, she not only contributes to the crystallization of the ideology of purism, of standardization, of an elitist (so-called) cultured norm, but also exercises the power of a teacher correcting an assignment in the light of the autonomous model of literacy.

The brief analysis of these two excerpts above points out that the language ideologies entextualized in fanfic multiliteracies practices have to do with the essentialized value of literate culture. This considers the canonic literature socially and culturally superior than fan literature and raises standard language, with emphasis on orthography, to a highly prestige level. These and other ideological 
questions regarding language and power are motivations for further studies aimed at understanding the multiliteracies practices in fanfic self-publishing platforms.

\section{FINAL REMARKS}

The main objective of this study was to discuss fanfic multiliteracies practices, in an attempt to describe the complexity of these contemporary practices occurring in the fandom universe. The analysis pointed out that fanfics involve literacy practices with multiple imbricated literacy events. Also, in the present time, due to the exponential growth of Wattpad self-publishing platform, we have been witnessing it capture the fan literature market niche.

In section 1, I discussed fanfics as ideological practices, shedding light to the new power relations between authors and readers who frequent the same affinity spaces and are allowed a much closer contact. I observed that in Spirit Fanfiction e Histórias, the negotiation of meanings between authors and readers can generate conflicts, such as disagreement or even outrage due to inconsistency in the stories or choices not expected/accepted by the fans. In section 1.1, I went on discussing fanfic multiliteracies practices focusing on the myriad of possible re-designs in increasingly multimodal and pluricultural settings. I dedicated some careful considerations to Fandom literacies, such as FanArt and Fancover.

In section 2, I focused on power relations in fan literature. To do so, I described some of the effects the socio-economical changes had in, on and around fanfic multiliteracies practices. I discussed some of the neoliberal market strategies Wattpad has been using to bring the fan literature from the fringes of the market to the hyper competitive entertainment industry. It is worth noting that Wattpad has joined well-known companies, such as Sony, Hulu, Macmillan, SYFY channel, among others, to work as partners of the branches Wattpad Books and Wattpad Studios.

The choice of the two platforms studied here - Spirit Fanfiction e Histórias and Wattpad - was grounded on their popularity and the fact they have already gone mobile. The social and technological changes provided by these platforms have reshaped our understanding of fan literature as it now: (i) incorporates social media communication practices in their platforms; (ii) involves fan engagement in affinity spaces other than the publishing platforms'; (iii) facilitates the design and re-design of discursive genres such as FanArt; (iv) enables the insertion of more digital multimodal recourses, such as songs and videos in the re-designing of the narratives; (v) weakens the power relations embedded in traditional editorial 
and publishing practices that control the processes of production, distribution, advertising and marketing, though it has been rapidly changing.

While conducting the study, another issue emerged and also became focus of reflection: the language ideologies entextualized by the fanfic readers who engage in fanfic multiliteracies practices. I drew on some literacy events consisting of round conversations within the scope of the PICJr-049 to problematize some questions concerning these fanfic readers' social use of language. On several occasions, they expressed ideologies regarding purism and language standardization as well as the privilege of the canonic literature at school against fan literature. In both excerpts discussed, I could observe how the literary genres of the Brazilian canon and spelling correction are highly valued even in an informal setting where, for not having the school's official patrol, could have been an opportunity to legitimize non-standardized variants of the prestige norm.

Building on what has been discussed so far, one of the contributions of this study is to start an ongoing dialogue by provoking a reflection on how fanfic multiliteracies practices can influence a new generation of readers and writers and how teachers and students could engage in literacy practices with literary genres. Another important reflection to be made is the appropriation of the amateur fan literature by the neoliberal market, reified by Wattpad, which is working with partners representing global multi-media entertainment companies. Copyright issues should be problematized as well. Thus, more studies in the ethnographic perspective, joining readers, writers and editors of fanfic or originals ${ }^{24}$, should be carried out in order to broaden our understanding of multiliteracies and language ideologies in contemporary fanfic literacy practices.

\section{REFERENCES}

BAKHTIN, M. (1979). Os gêneros do discurso. Organização, tradução, posfácio e notas de Paulo Bezerra. Notas da edição russa de Seguei Botcharov. São Paulo: Editora 34, 2016.

BARTON, D.; HAMILTON, M. (2000) Literacy practices. In Barton, D., Hamilton, M.; Ivanic, R. Situated Literacies: reading and writing in context. London: Routledge (Kindle Edition).

24. Stories which are not based on a fanfic or on a character of the Fandom universe. 
BAUMAN, R.; BRIGGS, C. (1990). Poetics and performance as critical perspectives on language and social life. Annual Review of Antbropology, Vol. 19, p. 59-88. Available in $<$ http://www.jstor.org/stable/2155959> Accessed on 07/03/2018.

BLOMMAERT, J. (2005). Discourse. Cambridge: Cambridge University Press.

BLOOME, D; KALMAN, J; SEYMOR, M. (2019). Fashioning Literacy as Social David Bloome, Judy Kalman, and Matt Seymour. In: BLOOME, D; CASTANHEIRA, M. L.; LEUNG, C; ROWSELL, J. Re-theorizing literacy practices: complex social and cultural contexts. 1.ed. New York: Routledge.

CANDIDO, A. (2002). Textos de intervenção. São Paulo: Duas cidades.

CAZDEN, C.; COPE, B.; FAIRCLOUGH, N.; GEE, J.; et al. (1996). A Pedagogy of Multiliteracies: Designing Social Futures. Harvard Educational Review; n. 66.1, p.60- 92.

COPE, B.; KALANTZIS, M. (eds). (2000) Multiliteracies: literacy learning and the design of social futures. London: Routledge.

FABRICIO, B. F. (2015). Policing the borderland in a digital lusophone territory: the pragmatics of entextualization. In MOITA LOPES, L. P. (Org.). Global Portuguese. Linguistic ideologies in late modernity. Nova York: Routledge (Kindle Edition).

FOUCAULT, M. (1980). Power/Knowledge. Brighton, UK: Harvester.

GEE, J.P. (2008). Social linguistics and literacies: ideologies in discourses. 3ed. London: Routledge, 1990.

GEE, J.P. (2004). Situated language and learning: a critique of traditional schooling. London: Routledge.

GEE, J.P. (2000). The New Literacy Studies; from "socially situated" to the work of the social. In Barton, D., Hamilton, M. and Ivanic, R. (2000) Situated Literacies: reading and writing in context. London: Routledge.

GEE, J.P. (2000). New people in new worlds: networks, the new capitalism and schools. In: COPE, B.; KALANTZIS, M. (Ed.). Multiliteracies: literacy learning and the design of social futures. London: Routledge.

GUIMARAES, T. F.; LOPES, L. P. da M. ( 2017 ). Trajetória de um texto viral em diferentes eventos comunicativos: entextualização, indexicalidade, performances identitárias e etnografia. Alfa, Rev. Linguíst. (São José do Rio Preto), São Paulo, v. 
61, n. 1, p. 11-33, mar. Available in <http://www.scielo.br/scielo.php?script $=$ sci arttext\&pid $=$ s1981-57942017000100011\&lng $=$ pt\&nrm $=$ iso $>$. Accessed on 07/25/ 2018.

HEATH, S.B.; STREET, B. (2008.) On etbnograpby: approaches to language and literacy research. New York: Teachers College Press, Columbia University.

HEATH, S. B. (1982). What no bedtime story means: Narrative skills at home and school. Language in Society, 11(1), p. 49-76

HELLEKSON, K.; BUSSE, K. (Eds.). (2014). The Fan Fiction Studies Reader. Iowa City: University of Iowa Press.

JENKINS, H. (1992). Textual poachers: television fans and participatory culture. Updated $20^{\text {th }}$ anniversary edition. New York: Routledge, 2013.

KLEIMAN, A. B.; SITO, L. (2016) Multiletramentos, interdições e marginalidades. In: KLEIMAN, A. B.; ASSIS, J. A. (org.). (2016) Significados e ressignificações do letramento: desdobramentos de uma perspectiva sociocultural sobre a escrita. Campinas, SP : Mercado de Letras.

KRESS, G.; ROWSELL, J. (2019). Literacy as a social practice: new realities and new models. In: BLOOME, D; CASTANHEIRA, M. L.; LEUNG, C; ROWSELL, J. (2019) Re-theorizing literacy practices: complex social and cultural contexts. 1.ed. New York: Routledge.

KROSKRITY, P. V. (2004). Language ideologies. In DURANTI, A. (ed.). A Companion to Linguistic Antbropology. Malden, MA: Blackwell Publishing.

LAJOLO, M. (2018). Literatura: ontem, boje, amanbã. São Paulo: Editora Unesp.

LUKE, C. ( 2000). Cyber-schooling and technological change: Multiliteracies for new times. In: COPE, B.; KALANTZIS, M. (Ed.). Multiliteracies: literacy learning and the design of social futures. London: Routledge.

MAYBIN, J. ( 2000). The new literacy studies: context, intertextuality and discourse. In: Barton, D.; Hamilton, M.; Ivanic, R. Situated Literacies: reading and writing in context. London: Routledge (Kindle Edition).

NEW LONDON GROUP GRUPO DE NOVA LONDRES. (2000) A Pedagogy of Multiliteracies: Designing Social Futures. In COPE, B.; KALANTZIS, M. 
(Ed.). (2000) Multiliteracies: literacy learning and the design of social futures. Routledge: Psychology Press, p.9-37.

ROJO, R. H. R. (2017) Entre Plataformas, ODAs e Protótipos: Novos multiletramentos em tempos de WEB2. The Especialist, v. 38, p. 1-20. Available in <https://revistas.pucsp. br/index.php/esp/article/view/32219>. Accessed on 04/16/2018.

ROJO, R. H. R. (2012) Pedagogia dos Multiletramentos: diversidade cultural e de linguagens na escola. In: ROJO, R. H. R.; MOURA, E. (Orgs.) Multiletramentos na Escola. SP: Parábola.

SILVERSTEIN, Mi URBAN, G. (1996). The natural history of discourse. In: SILVERSTEIN, Mi URBAN, G (Orgs.). Natural bistories of discourse. Chicago: University of Chicago Press.

STREET, B. (2012). Eventos de letramento e práticas de letramento: teoria e prática nos novos estudos do letramento. In: MAGALHÃES, I. Discursos e práticas de letramento: pesquisa etnográfica e formação de professores. Campinas, SP: Mercado de Letras.

STREET, B. (2003). What's "new" in New Literacy Studies? Critical approaches to literacy in theory and practice. Current Issues in Comparative Education, Vol. 5 (2), p. 77-91.

STREET, B. (1995). Letramentos sociais: abordagens críticas do letramento no desenvolvimento, na etnografia e na educação. Trad.: Marcos Bagno. São Paulo: Parábola, 2014.

STREET, B. (1984). Literacy in theory and practice. Cambridge: CUP.

SZUNDY, P. T. C. (2017). Language ideologies on in Brazil: conflicting positions expressed by undergraduate students. The Journal of English as a Lingua Franca, V. 6, pp 167-192.

VOLÓCHINOV, V. (1929). Marxismo e filosofia da linguagem: problemas fundamentais do método sociológico na ciência da linguagem. Tradução, notas e glossário de Sheila Grillo e Ekaterina Vólkova Américo. Ensaio introdutório de Sheila Grillo. São Paulo: Editora 34, 2017.

WOOLARD, K. A. (1998). Introduction. B. B. SCHIEFFELIN, K. A. WOOLARD, P. V.; KROSKRITY, P. V. (Eds.). (1998). Language ideologies practice and theory. Oxford: Oxford University Press, v.3, n.4. 


\section{APPENDIX 1}

Figure 1: Reader's comment

In this translation, I have opted to keep the author's style, punctuation and language structure. Words marked with an * indicate my attempt to preserve spelling and/or grammatical mistakes made in the original language.

Yui_chan2 (posted 02/07/2018 11:32)

This is one more chapter that bugs my mind, simple since sasuke said he didn't like her (actually, he didn't say that, he acted that way) why didn't he jusst* go out with the woman who came ontto* him? At that time I thought he was doing this out of respect for saky even though he didn't feel anything for her I think or maybe he didn't want to "do lepo lepo" [neologism indicating sexual intercourse]so he wouldn't get any more children, IDK [I don't know] I'm really confused.

Another thing sakura my god man how come the guy has treated her so badly and she even behaved as a possessive woman Saky my love if he doesn't love you and you're both going to get married in my opinion I'm sure there will be nice men later but she will be married to a jerk (no offense but that's it indeed ' - ') then she will start to like this guy uchiha will get to know he will act as a possessive man, then he will make that scene she will be confused whether or not he loves her he will keep denying his feelings just wanting to keep Sakura because of his daughter C'MON THAT'S ENOUGH.

Another thing I really wanted to know about Sarada because how will she react when she knows that the father doesn't like (Love) Saky or IDK [I don't know] if she knows that he abandoned sakura eight years ago, I swear I got goose bumps when she found her father, bro I HATED UCHIHA for treating saky so badly.

Ino is not to blame for that you know guys, because she was trying to protect her friend, she put herself in her friend's shoes, and that threat, man I already knew that saky would never run away without talking to her best friend. Itachi confessd* he should really be upset with ino right but soon it's over they make a perfect couple, I'm sure that soon they make things worq*', and Love love Love love here Love love Love Love there. 
Author you asked for comments here you are a giant one for you to read sorry if I make you tired it was not my intention right? I just wanted to make clear my indignation with uchiha and also support the story it was top [excellent], ok?

Kissessss : 3

\section{Answered by Envied 02/07/2018 11:44}

I love long comments, I know it is complex, it is difficult to understand but everything will fall into place. This is true even bc [because] nothing makes sense at the beginning but the [sic]end.

In this translation, I have opted to keep the author's style, punctuation and language structure.

Recebido: 8/10/2019

Aceito: $2 / 01 / 2020$

Publicado: 2/03/2020 